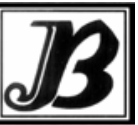

J. bio-sci. 16: 95-99, 2008

ISSN 1023-8654

http://www.banglajol.info/index.php/JBS/index

\title{
STUDIES ON THE SUGAR ACCUMULATION AND CARBOHYDRATE SPLITTING ENZYME LEVELS IN POST HARVESTED AND COLD STORED POTATOES
}

\author{
Md Rezaul Karim¹, M M H Khan*, Md Salim Uddin, N K Sana, F Nikkon and Md Habibur Rahman \\ Department of Biochemistry \& Molecular Biology, University of Rajshahi, Rajshahi-6205, Bangladesh. \\ ${ }^{1}$ Department of Applied Nutrition \& Food Technology, Islamic University of Kushtia, Bangladesh
}

\begin{abstract}
Significant differences were found in sugar content and carbohydrate splitting enzyme activities in tubers of ten indigenous potato varieties at harvesting and after keeping at cold storage. The activities of invertase, amylase, $\beta$-galactosidase and cellulase in all varieties were found to be increased by $2-12$, 1.2-4, 1.9-4.5, and 1.1-3.7 folds, respectively from harvesting to cold stored potatoes. The amount of starch and sucrose were found to be decreased by 1.15-2.8 and 1.02-1.4 folds, respectively from harvesting to cold stored in all varieties. Total soluble sugar and reducing sugar contents in potatoes were increased by 1.02-1.4 and 4-11 folds, respectively from harvesting to cold stored in all varieties of potatoes. The amount of reducing sugar increased in cold stored potatoes due to the increased activities of carbohydrate splitting enzymes.
\end{abstract}

Key words: Potatoes, Indigenous, Carbohydrate splitting enzymes, Sugars.

\section{Introduction}

Potato (Solanum tuberosum) is an important vegetable crop in Bangladesh and occupying third position, after rice and wheat. Potato is not indigenous crop of Bangladesh. It is a staple food in more than 40 countries and it is used for human consumption, animal feed and industrial raw material. It is an excellent source of starch, proteins, iron, phosphorus, calcium, carotene, thiamine, riboflavin and vitamin-c (Bradbury and Holloway 1988, Wheatly et al. 1995). The chemical compositions of potatoes are greatly affected by variety, environment and farming conditions (Cargill et al. 1986, Forbush 1989). Potato tubers contain 9 to $25 \%$ carbohydrate (Cacees and Pedro 1991) and it was reported that the quantity and quality of carbohydrate changes with the changes of temperature. Storing at low temperature can lead to sweetening of potatoes due to the accumulation of reducing sugars (Uppal and Verma 1990, Wismer et al. 1995). At low temperature some of the carbohydrate splitting enzymes may get activation and play some important role for the sweetening of potato. This study was carried out to ascertain the relationship of sugar content and some carbohydrate splitting enzymes in ten different indigenous varieties of potato at harvesting (mature) and after keeping in cold storage at $30-35^{\circ} \mathrm{F}$ for 8 weeks.

\section{Materials and Methods}

The varieties Ausha, Challisha, Lal pakri, Lal shil, Patnai, Shada guti, Shil bilati, Jolpai, TPS-67 and TPS-7 were collected from the plant Breeding and Biotechnology Laboratory, Department of Botany, Rajshahi University, Bangladesh.

\footnotetext{
*Corresponding author: e-mail: muktabio@yahoo.com
} 
Enzyme assay: About $50 \mathrm{~g}$ of potato were peeled and cut into small pieces and homogenized well with cold buffer of respective $\mathrm{pH}$ (for amylase, invertase, cellulase: $0.1 \mathrm{M}$ sodium acetate buffer, $\mathrm{pH} 6, \mathrm{pH} 5$ and $\mathrm{pH}$ 5.2 , respectively and $\beta$-D-galactosidase: sodium citrate buffer, $\mathrm{pH} 4.1$ ). The extracts were filtered by few layer of cheesecloth and further clarified by centrifugation at $6000 \mathrm{rpm}$ for 15 minutes at $4^{\circ} \mathrm{C}$. The clear supernatant was collected and used as crude enzyme extract.

Amylase, invertase and cellulase activities were assayed as described by Mahadevan and Sridhar (1982) using starch $(1 \%)$, sucrose $(2.5 \%)$ and carboxymethyl cellulose $(0.5 \%)$ solution as substrate, respectively. One unit of amylase activity was defined as the amount required for liberating $1 \mathrm{~g}$ of glucose from starch per minute at $37^{\circ} \mathrm{C}$. One unit of invertase activity was defined as the amount required for liberating $1 \mathrm{~g}$ of glucose and fructose from the breakdown of sucrose per minute at $37^{\circ} \mathrm{C}$. Cellulase activity was measured by estimating the reducing sugar released from substrate by cellulase using dinitrosalicylic acid method (Miller 1972). One unit of cellulase activity was defined as the amount of enzyme required for liberating $1 \mathrm{~g}$ of reducing sugar from $\mathrm{CMC}$ per minute at $37^{\circ} \mathrm{C}$. $\beta$-galactosidase activity was assayed by the method of Lazan et al. (1993). Amount of galactose released was estimated by dinitrosalicylic acid method (Miller 1972). One unit of $\beta$-galactosidase activity was defined as the amount of enzyme that catalyzed the liberating of $1 \mathrm{~g}$ of galactose per minute at $37^{\circ} \mathrm{C}$.

Estimation of starch, total soluble sugar, sucrose and reducing sugar: Total soluble sugar and starch in potato were determined colorimetrically by the anthrone method (Jayaraman 1985). Reducing sugar content was determined by dinitrosalicylic acid method (Miller 1972).

\section{Results and Discussion}

The activities of different enzymes, amount of starch, total soluble sugar, sucrose and reducing sugar in ten different indigenous potato varieties (IPVs) at harvesting and in cold stored condition are shown in Table 1. Invertase, a carbohydrate splitting enzyme, plays an important role in the hydrolysis of sucrose to glucose and fructose. Invertase activities in different varieties of potato at harvesting stage were ranged from 6.66 to $24 \mathrm{U} / \mathrm{ml}$ and from 34 to $116 \mathrm{U} / \mathrm{ml}$ at cold stored conditions. Among the varieties, the invertase activity was found to be highest in Shil bilati $(24 \mathrm{U} / \mathrm{ml})$ and lowest in Ausha $(6.66 \mathrm{U} / \mathrm{ml})$ at harvesting stage. After cold stored, Jolpai and Shada guti contained the highest $(116 \mathrm{U} / \mathrm{ml})$ and lowest $(34 \mathrm{U} / \mathrm{ml})$ amount of invertase activities, respectively. The activities of invertase in all varieties were found to be increased about 2 to 12 folds from harvesting to cold stored conditions. Similar trends were also reported by llleperuma et al. (1998), Geracimo and John (1990), Uppal and Verma (1990) and Richardson et al. (1990).

Amylase is a carbohydrate splitting enzyme, which hydrolyzes starch to yield monomeric carbohydrates. Amylase activities in different varieties were varied between 22 to $67 \mathrm{U} / \mathrm{ml}$ in harvesting and 26 to $210 \mathrm{U} / \mathrm{ml}$ after keeping at cold stored conditions (Table 1). Of the varieties, TPS-67 contained the highest $(67 \mathrm{U} / \mathrm{ml})$ and TPS-7 contained lowest $(22 \mathrm{U} / \mathrm{ml})$ amylase activities at harvesting stage. After cold stored, Lal pakri contained the highest amount $(210 \mathrm{U} / \mathrm{ml})$ of amylase activities followed by Ausha $(161 \mathrm{U} / \mathrm{ml})$, Shada guti (139 $\mathrm{U} / \mathrm{ml})$, Shil bilati $(117 \mathrm{U} / \mathrm{ml})$ and so forth. The lowest activity $(26 \mathrm{U} / \mathrm{ml})$ was found in cold stored TPS-7 potato variety. The activities of amylase were found to be increased 1.2 to 4 folds from harvesting to cold stored conditions in different varieties. Similar activities pattern in potatoes were also reported by Nielsen et al. (1997), Cochrane et al. (1991) and Hill et al. (1996).

$\beta$-galactosidase, a carbohydrate splitting enzyme, plays a significant role in plant tissues especially after maturation of fruits. The activities of $\beta$-galactosidase in different varieties were found to be ranged from 5.74 
$\mathrm{U} / \mathrm{ml}$ to $14.66 \mathrm{U} / \mathrm{ml}$ and $13.6 \mathrm{U} / \mathrm{ml}$ to $37 \mathrm{U} / \mathrm{ml}$ in harvesting and cold stored conditions, respectively (Table 1). Among the varieties, the activity $\beta$-galactosidase was present to be highest in Patnai $(14.66 \mathrm{U} / \mathrm{ml})$ and lowest in Lal pakri variety $(5.74 \mathrm{U} / \mathrm{ml})$ at harvesting stage. After cold stored, the maximum amount of $\beta$ galactosidase activity was found in Jolpai $(37 \mathrm{U} / \mathrm{ml})$ followed by Ausha $(32.8 \mathrm{U} / \mathrm{ml})$, Patnai $(31 \mathrm{U} / \mathrm{ml})$, Shada guti $(27 \mathrm{U} / \mathrm{ml})$ and so forth. The activities of $\beta$-galactosidase in all varieties of potatoes were found to be increased by 1.9 to 4.5 folds from harvesting to cold stored conditions.

Table 1. Activities of amylase, invertase, cellulase, $\beta$-D-galactosidase and its relation to sugar accumulation in potato at harvesting and after keeping at cold storage (within parenthesis) conditions.

\begin{tabular}{|c|c|c|c|c|c|c|c|c|}
\hline \multirow{2}{*}{ Varieties } & \multicolumn{4}{|c|}{ Enzyme (unit/ml) } & \multicolumn{4}{|c|}{ Composition (g\%) } \\
\hline & Invertase & Amylase & $\beta$-D-galactosidase & Cellulase & Starch & Soluble sugar & Reducing Sugaı & Sucrose \\
\hline Ausha & $\begin{array}{l}6.66 \pm 0.002 \\
(55.5 \pm 0.01)\end{array}$ & $\begin{array}{c}54.66 \pm 0.01 \\
(161 \pm 0.008)\end{array}$ & $\begin{array}{c}12.26 \pm 0.0015 \\
(32.8 \pm 0.002)\end{array}$ & $\begin{array}{c}2.66 \pm 0.001 \\
(6.77 \pm 0.002)\end{array}$ & $\begin{array}{c}8.5 \pm 0.05 \\
(5.82 \pm 0.03)\end{array}$ & $\begin{array}{c}4.44 \pm 0.1 \\
(4.73 \pm 0.1) \\
\end{array}$ & $\begin{array}{c}0.17 \pm 0.04 \\
(1.45 \pm 0.11) \\
\end{array}$ & $\begin{array}{c}4.22 \pm 0.1 \\
(3.12 \pm 0.12) \\
\end{array}$ \\
\hline Lal pakri & $\begin{array}{c}20.66 \pm 0.004 \\
(62 \pm 0.008)\end{array}$ & $\begin{array}{l}60.13 \pm 0.02 \\
(210 \pm 0.08)\end{array}$ & $\begin{array}{c}5.74 \pm 0.003 \\
(13.6 \pm 0.001)\end{array}$ & $\begin{array}{l}5.95 \pm 0.0025 \\
(6.33 \pm 0.002)\end{array}$ & $\begin{array}{l}11.48 \pm 0.03 \\
(4.63 \pm 0.07)\end{array}$ & $\begin{array}{c}2.5 \pm 0.2 \\
(2.65 \pm 0.1)\end{array}$ & $\begin{array}{c}0.05 \pm 0.01 \\
(0.20 \pm 0.10)\end{array}$ & $\begin{array}{c}2.38 \pm 0.2 \\
(2.32 \pm 0.1)\end{array}$ \\
\hline Lal shil & $\begin{array}{l}17.2 \pm 0.002 \\
(64 \pm 0.004)\end{array}$ & $\begin{array}{c}27.66 \pm 0.006 \\
(108 \pm 0.02)\end{array}$ & $\begin{array}{c}8.52 \pm 0.007 \\
(18.6 \pm 0.003)\end{array}$ & $\begin{array}{l}0.95 \pm 0.003 \\
(3.5 \pm 0.001)\end{array}$ & $\begin{array}{l}12.43 \pm 0.06 \\
(4.47 \pm 0.05)\end{array}$ & $\begin{array}{c}6.95 \pm 0.4 \\
(7.53 \pm 0.6)\end{array}$ & $\begin{array}{c}0.14 \pm 0.02 \\
(1.31 \pm 0.08)\end{array}$ & $\begin{array}{c}6.65 \pm 0.4 \\
(5.91 \pm 0.55)\end{array}$ \\
\hline Patnai & $\begin{array}{l}16.33 \pm 0.01 \\
(64 \pm 0.005)\end{array}$ & $\begin{array}{l}56 \pm 0.0015 \\
(84 \pm 0.007)\end{array}$ & $\begin{array}{c}14.66 \pm 0.004 \\
(31 \pm 0.005)\end{array}$ & $\begin{array}{c}3.75 \pm 0.002 \\
(3.93 \pm 0.001)\end{array}$ & $\begin{array}{c}8.2 \pm 0.08 \\
(7.15 \pm 0.06)\end{array}$ & $\begin{array}{l}2.63 \pm 0.3 \\
(3.5 \pm 0.2)\end{array}$ & $\begin{array}{c}0.12 \pm 0.02 \\
(0.91 \pm 0.09)\end{array}$ & $\begin{array}{c}2.5 \pm 0.3 \\
(2.46 \pm 0.15)\end{array}$ \\
\hline Shada guti & $\begin{array}{c}19.33 \pm 0.008 \\
(34 \pm 0.007) \\
\end{array}$ & $\begin{array}{c}62 \pm 0.03 \\
(139 \pm 0.02) \\
\end{array}$ & $\begin{array}{c}12.26 \pm 0.003 \\
(27 \pm 0.001) \\
\end{array}$ & $\begin{array}{c}4.14 \pm 0.003 \\
(7.33 \pm 0.008) \\
\end{array}$ & $\begin{array}{c}9.03 \pm 0.09 \\
(5.93 \pm 0.01)\end{array}$ & $\begin{array}{c}5.05 \pm 0.4 \\
(5.15 \pm 0.1) \\
\end{array}$ & $\begin{array}{c}0.09 \pm 0.01 \\
(0.75 \pm 0.07)\end{array}$ & $\begin{array}{c}4.8 \pm 0.4 \\
(4.18 \pm 0.11) \\
\end{array}$ \\
\hline Shil bilati & $\begin{array}{l}24 \pm 0.005 \\
(87 \pm 0.02)\end{array}$ & $\begin{array}{c}58 \pm 0.006 \\
(117 \pm 0.01) \\
\end{array}$ & $\begin{array}{c}6.12 \pm 0.003 \\
(20.4 \pm 0.004) \\
\end{array}$ & $\begin{array}{c}5.05 \pm 0.006 \\
(5.44 \pm 0.002) \\
\end{array}$ & $\begin{array}{c}9.41 \pm 0.06 \\
(7.76 \pm 0.02) \\
\end{array}$ & $\begin{array}{l}4.25 \pm 0.09 \\
(4.75 \pm 0.2)\end{array}$ & $\begin{array}{c}0.08 \pm 0.01 \\
(0.87 \pm 0.11) \\
\end{array}$ & $\begin{array}{r}4.03 \pm 0.09 \\
(3.68 \pm 0.19) \\
\end{array}$ \\
\hline Challisha & $\begin{array}{l}8.78 \pm 0.003 \\
(80 \pm 0.002)\end{array}$ & $\begin{array}{c}63.3 \pm 0.02 \\
(93.5 \pm 0.006)\end{array}$ & $\begin{array}{c}13.6 \pm 0.003 \\
(25.2 \pm 0.008)\end{array}$ & $\begin{array}{c}3.4 \pm 0.001 \\
(4.3 \pm 0.002)\end{array}$ & $\begin{array}{c}8.2 \pm 0.07 \\
(6.86 \pm 0.02)\end{array}$ & $\begin{array}{c}2.79 \pm 0.1 \\
(3.21 \pm 0.05)\end{array}$ & $\begin{array}{c}0.19 \pm 0.01 \\
(1.21 \pm 0.12)\end{array}$ & $\begin{array}{l}2.66 \pm 0.16 \\
(1.9 \pm 0.12)\end{array}$ \\
\hline Jolpai & $\begin{array}{c}9.35 \pm 0.01 \\
(116 \pm 0.04(\end{array}$ & $\begin{array}{l}45.8 \pm 0.02 \\
(61 \pm 0.02)\end{array}$ & $\begin{array}{c}8.2 \pm 0.008 \\
(37 \pm 0.002)\end{array}$ & $\begin{array}{c}2.8 \pm 0.002 \\
(3.85 \pm 0.003)\end{array}$ & $\begin{array}{c}10.2 \pm 0.07 \\
(8.82 \pm 0.09)\end{array}$ & $\begin{array}{c}4.35 \pm 0.09 \\
(5.76 \pm 0.06)\end{array}$ & $\begin{array}{c}0.21 \pm 0.03 \\
(1.48 \pm 0.09)\end{array}$ & $\begin{array}{c}4.13 \pm 0.2 \\
(4.07 \pm 0.35)\end{array}$ \\
\hline TPS-67 & $\begin{array}{l}10.5 \pm 0.009 \\
(75 \pm 0.006)\end{array}$ & $\begin{array}{c}67 \pm 0.008 \\
(105.66 \pm 0.06)\end{array}$ & $\begin{array}{l}7.8 \pm 0.003 \\
(16 \pm 0.02)\end{array}$ & $\begin{array}{c}3.8 \pm 0.004 \\
(5.2 \pm 0.001)\end{array}$ & $\begin{array}{c}7.8 \pm 0.01 \\
(5.88 \pm 0.04)\end{array}$ & $\begin{array}{c}2.27 \pm 0.1 \\
(2.74 \pm 0.1) \\
\end{array}$ & $\begin{array}{l}0.09 \pm 0.001 \\
(0.85 \pm 0.09)\end{array}$ & $\begin{array}{c}2.15 \pm 0.06 \\
(1.79 \pm 0.12)\end{array}$ \\
\hline TPS-7 & $\begin{array}{l}7.2 \pm 0.005 \\
(56 \pm 0.02)\end{array}$ & $\begin{array}{l}22 \pm 0.003 \\
(26 \pm 0.02)\end{array}$ & $\begin{array}{c}9.2 \pm 0.002 \\
(21.6 \pm 0.03)\end{array}$ & $\begin{array}{c}2.3 \pm 0.002 \\
(4.66 \pm 0.003)\end{array}$ & $\begin{array}{c}7.05 \pm 0.07 \\
(5.53 \pm 0.02)\end{array}$ & $\begin{array}{c}2.9 \pm 0.2 \\
(3.6 \pm 0.3)\end{array}$ & $\begin{array}{c}0.12 \pm 0.01 \\
(1.15 \pm 0.11)\end{array}$ & $\begin{array}{c}2.75 \pm 0.3 \\
(2.32 \pm 0.23)\end{array}$ \\
\hline
\end{tabular}

Cellulase is also a carbohydrate splitting enzyme, which is responsible for release of glucose from cellulose. The cellulase activities of the different indigenous potato varieties at harvesting and cold stored are given in the Table 1. Of the varieties, the activities of cellulase were highest in Lal pakri $(5.95 \mathrm{U} / \mathrm{ml})$ and lowest in Lal shil $(0.95 \mathrm{U} / \mathrm{ml})$ at harvesting stage. After cold stored, Shada guti contained the highest amount $(7.33 \mathrm{U} / \mathrm{ml})$ of cellulase activities followed by Ausha $(6.77 \mathrm{U} / \mathrm{ml})$, Lal pakri $(6.33 \mathrm{U} / \mathrm{ml})$, Shil bilati $(5.44 \mathrm{U} / \mathrm{ml})$ and so forth. The lowest activity was found in Lal shil $(3.5 \mathrm{U} / \mathrm{ml})$ after keeping at cold storage. Although the amount of cellulase activity was low compare to other, activities of cellulase were found to be increased by 1.1 to 3.7 folds from harvesting to cold stored in all varieties of potatoes.

Starch is the principal storage carbohydrate in plant cells. The amount of starch in different varieties of potato was found to be varied between $7.05 \%-12.43 \%$ and $4.47 \%-8.82 \%$ in harvesting and cold stored, respectively (Table 1). Lal shil contained highest amount of starch (12.43\%) and TPS-7 contained lowest $(7.05 \%)$ at harvesting stage. After cold stored, Jolpai contained the highest amount of starch $(8.82 \%)$ followed by Shil bilati $(7.76 \%)$, Patnai $(7.15 \%)$, Challisha $(6.86 \%)$ and so forth. The amounts of starch were found to be decreased $(1.15-2.8$ folds) from harvesting to cold stored conditions in all the varieties. Prolonged exposure to low temperature can result in potato starch conversion to reducing sugar. The amount of starch is reduced due to the hydrolysis of starch by starch degrading enzymes. Similar finding were reported by Nielsen et al. (1997), Cochrane et al. (1991). 
The total soluble sugar contents of ten indigenous potato varieties were analyzed and the results are summarized in Table 1. Total soluble sugar contents were increased moderately in cold stored potato. Of the varieties examined, Lal shil contained the highest amount of total soluble sugar $(6.95 \%)$ while TPS-67 contained the lowest amount $(2.27 \%)$ at harvesting stage. Among the varieties, Lal shil contained the highest amount of total soluble sugar in both stages $(6.95 \%$ and $7.53 \%$ in harvesting and cold stored, respectively). After cold stored, the amount of total soluble sugar varied between 2.65\% (Lal Pakri) to $7.53 \%$ (Lal shil). The amount of total soluble sugar in all the varieties was found to be increased (1.02 - 1.4 folds) from harvesting to cold stored conditions. Increased total soluble sugar content might be due to enzymatic hydrolysis of starch to sugar at low temperature (Cochrane et al. 1991, Nielsen et al. 1997).

The reducing sugar content of the potato is affected by several factors, including variety, growing conditions, maturity at harvest, post harvest handling stress and the storage environment (Cargill et al. 1986, Forbush 1989, Uppal and Verma 1990). As shown in Table 1, the reducing sugar contents were found to be varied between $0.05-0.21 \%$ and $0.20-1.48 \%$ at harvesting and cold stored potatoes. After cold stored conditions, Jolpai cultivar contained the highest amount of reducing sugar (1.48\%) followed by Ausha (1.45\%), Lal shil $(1.31 \%)$, Challisha $(1.21 \%)$, TPS-7 $(1.15 \%)$ and so forth. Of the varieties, Jolpai contained the highest amount $(0.21 \%)$ and the Lal pakri contained the lowest amount $(0.05 \%)$ of reducing sugar at harvesting stage. The amount of reducing sugar in all the varieties of potato was found to be increased (4-11 folds) from harvesting to cold stored. The amount of reducing sugar increased in cold stored potato due to the enzymatic conversion of starch and sucrose to reducing sugar (Illeperuma et al. 1998, Uppal and Verma 1990, Nielsen et al. 1997).

Sucrose is an early product of photosynthetic reaction and is the most abundant transportable free carbohydrate in the plant kingdom. It was found that Lal shil contained the highest amount of sucrose $(6.65 \%)$ and TPS-67 contained the lowest amount (2.15\%) at harvesting stage. After keeping at cold storage, the amount of sucrose varied between $1.79 \%$ (TPS-67) to $5.91 \%$ (Lal shail). The amount of sucrose was found to be decreased (1.02-1.4 folds) from harvesting to cold stored in all varieties. The result was correlated well with the increased activities of invertase from harvesting to cold stored potatoes. The increased activity of invertase is associated with the decreased amount of sucrose content in potato reported by Uppal and Verma (1990) and Richardson et al. (1990).

\section{References}

Bradbury J H and Holloway W D (1988) Chemistry of tropical root crops: Significance for nutrition and agriculture in the pacific. Australian Centre for International Agriculture Research (ACIAR), Monograph Series No. 6. Canberra, Australia

Cacees $L$ and Pedro A (1991) Yields factor in starch production in potato. Valdiva (Chile) 9.

Cargill B F, Ledebuhr R L, Price K C and Forbush T D (1986) Influence of prestorage chemical treatments on out-ofstorage market quality of potatoes. In: engineering for potatoes, B F Cargill, ed. ASAE, St. Joseph, MI.

Cochrane M P, Duffus C M, Allison M J and Mackay G R (1991) 1. Amylase activity in potato tubers. 2.The effect of lowtemperature storage on the activities of alpha and beta amylase and alpha glucosidase in potato tubers. J. Potato Res. 34(4): 333-341.

Forbush T D (1989) Influence of ventilation rate on potato quality out of storage. M S Thesis. Michigan State University.

Geracimo E B and John R W (1990) Purification and partial characterization of potato invertase and its endogenous proteinaceous inhibitors. Plant Physiol. 92: 386-394. 
Hill L, Reimholz R, Schroder R and Stilt M (1996) A new starch-degrading enzyme activity is induced by storage of potato tubers at low temperature. Plant Cell Environ. 14: 1223-1237.

Illeperuma C, Schlimme D and Solomos T (1998) Changes in sugars and activities of sucrose phosphate synthase, sucrose synthase, and invertase during potato tuber (Russet Burbank) reconditioning at $10^{\circ} \mathrm{C}$ in air and $2.53 \mathrm{kPa}$ oxygen after storage for 28 days at $1^{\circ} \mathrm{C}$. J. Am.Soc. Hortic. Sci. 123: 311-316.

Jayaraman J (1985) Laboratory manual in Biochemistry (1 ${ }^{\text {st }}$ ed.). Wiley Eastern Ltd, New Delhi.

Lazan A, Ali Z M and Soh J S (1993) $\beta$-Galactosidase, polygalacturonase and pectinesterase in differential softening and cell wall modification during papaya fruit ripening. Acta Hortic. 341: 500 - 509.

Mahadevan A and Sridhar R (1982) Method in physiological Plant Pathology. Sivakami Publication. Madras, 316.

Miller G L (1972) Use of DNS reagent for the determination of glucose. Anal. Chem. 31: 426-428.

Nielsen T H, Deiting U and Stilt M A (1997) Amylase in potato tubers is induced by storage at low temperature. Plant Physiol. 113(2): 503-510.

Richardson D L, Davies H V, Ross H A and Mackay G R (1990) Invertase activity and its relation to hexose accumulation in potato tubers. J. Exp. Bo. 41(222): 95-99.

Uppal D S and Verma S C (1990) Changes in the sugar content and invertase activity in tubers of some Indian potato varieties stored at low temperature. Division of Crop Physiology and Biochemistry, Central Potato Research Institute, Shimla 17001, Himachal Pradesh, India. Potato-Res. 33(1): 119-123.

Wheatly C, Scoot G J and Wiersema S (1995) Adding value to root and tuber crops. A manual on product development. Cali, Colombia: Centre International de Agricultura Tropical (CIAT).

Wismer W V, Marangoni A G and Yada R Y (1995) Low temperature sweetening in roots and tubers. Hort. Rev.17: 203-231. 